\title{
Knowledge, Protection, Conservation and Management in the Marine Domain: The Example of the Mainland French Coast
}

\author{
Gérard Bellan*,1, Jean-Claude Dauvin ${ }^{2,3}$ and Denise Bellan-Santini ${ }^{1}$ \\ ${ }^{I}$ Centre d'Océanologie de Marseille, UMR CNRS DIMAR 6540, Université de la Méditerranée, Station Marine \\ d'Endoume, Rue Batterie des Lions, F-13007 Marseille, France \\ ${ }^{2}$ Université Nord de France F-59000 Lille, France \\ ${ }^{3}$ Université de Lille 1, CNRS UMR 8187 LOG, Station Marine de Wimereux, 28 Avenue Maréchal Foch, B.P. 80, F- \\ 62930 Wimereux, France
}

\begin{abstract}
France is geographically located in a central maritime position within the European Union (EU). Consequently, the experience gained and the solutions proposed in France may be of interest within a much wider geographical and institutional framework. The EU directives and regulations and the international treaties and conventions bind it. Among the 'tools' for environmental protection and management of the environment, we must point out: the Conservatory of Coastal Areas and Lakeshores, the 'Littoral' Law of 1 March 1986, the international conventions and European Directives (birds and habitats), the Inventory of the Flora and Fauna in Natural Marine Zones of Ecological Interest (ZNIEFF-Mer), the Mediterranean Blue Plan, the Barcelona Convention. More specially, we would enhance the practical interest, in the frame of the France's Strategic Action Plan for the marine environment, of the ZNIEFFs-Mer, the LITEAU (Littoral Eau) Program of the Ministry of the Environment, the French Marine Protected Areas Agency (MPAA). They are likely to lead to the protection of the littoral marine environment and beyond in the EEZ (Exclusive Economic Zone), along with a reasoned sustainable management of this environment. Integrated Coastal Zone Management (ICZM) is the method that has the best chance of success. In addition, the international scientific community has developed the concept of ecosystem-based management of marine resources, integrating a distinct human component into this 'eco-socio-system'. The role and the authority of the European Environment Agency must be increased in order to strengthen the cooperative links between the scientists in European countries.
\end{abstract}

Keywords: Protection, management, marine domain, France.

\section{INTRODUCTION}

France, with its 11 million $\mathrm{km}^{2}$ of marine territory in EEZ (Exclusive Economic Zone), is present in all the oceans of the world, except the Arctic. The country's marine territories cover more than $10 \%$ of the world's coral reefs. It plays a very important role in accumulating knowledge about the world's natural heritage and marine resources, as well as knowledge about their exploitation, protection and conservation and thus the sustainable management of the sea. But, it is only recently, at the beginning of 1970 s, that France, strongly rooted in the land, has begun reaching out decisively towards the sea. The successive administrations of not only the former French monarchies but also the country's first Republics, particularly after Napoleon's great sea defeats at the beginning of the 19th century, attempted to protect the country's terrestrial borders and develop the richness of its agriculture. The French Navy, maritime transport and fishing would develop over the course of time but without any true national environmental protection policy.

*Address correspondence to this author at the Centre d'Océanologie de Marseille, UMR CNRS DIMAR 6540, Université de la Méditerranée, Station marine d'Endoume, Rue Batterie des Lions, F-13007 Marseille, France; Tel: +33 49104 16 12; Fax: 3349104 16 35;

E-mail: gerard.bellan@univmed.fr
The Ministry of the Environment was created relatively recently, in 1971. National and regional parks were first created inland. It wasn't until 1963 that the first national marine park was created at Port-Cros in the Mediterranean, and it remains the only park on the coast of mainland France that is both terrestrial and marine. In fact, in such a centralist country as France, most laws and regulations focus first on its European territory and then extend towards overseas departments, which are part of the European Union. For the other ultra-marine territories, the local and territorial authorities leave the mainland French authorities behind with regard to the environment.

France is geographically located in a central maritime position within the EU and, among others, has coastline along the northwestern basin of the Mediterranean. It is bound by the EU directives and regulations and the international treaties and conventions, such as the OSPAR (Oslo Paris Convention) and Barcelona Conventions, and its marine prevention and management options are essentially dependent on these measures. Consequently, the experience gained and the solutions proposed in France may be of interest within a much wider geographical and institutional framework.

In this article, we focus only on mainland Metropolitan France and its $5,500 \mathrm{~km}$ of coastline. We will base our 
discussion on the key stages, regulations and measures in the implementation over time of an international point of view then we describe national marine strategy for the protection and management of the marine domain since the 1975 creation of the Conservatory of Coastal Areas and Lakeshores ('Conservatoire des Espaces Littoraux et des Rivages Lacustres', CELRL) for mainland France, from the Littoral Law in 1986. We also propose a review of the lands acquired by the CELRL and the marine protected areas strategy of the recently created French Marine Protected Areas Agency ('Agence des Aires Marines Protégées,' AAMP) the main aim is to support public policies in the field of marine protected areas, both concerning their creation and their management. Finally, we present a brief analysis of the French ambitions in relation to the available means that exist to carry out this policy successfully.

\section{CHARACTERISTICS OF THE COASTLINE OF MAINLAND FRANCE}

The length of the French mainland coastline (Fig. 1) is around $5,500 \mathrm{~km}$, including $3,600 \mathrm{~km}$ on the west coast (English Channel/North Sea; Atlantic Ocean) and 1,700 km on the Mediterranean coast [1,2] This coastline can be broadly divided into three categories: $30 \%$ rocky, $40 \%$ sandy and $30 \%$ muddy marshland.

\subsection{Characteristics of the English Channel and the southern part of the North Sea}

The English Channel like the southern part of the North Sea is a not very deep (average $50 \mathrm{~m}$ ) epicontinental seas with a well-developed seashore and strong tides $(>13 \mathrm{~m}$ in Mount Saint-Michel Bay). A bio-geographical crossroad, the English Channel has less extensive ecological conditions than other European seas, with benthic habitats in mosaic patterns, particularly in the western section of the Channel. It has predominately coarse sand and gravel bottoms in the subtidal zone due to the force of the tidal currents [1, 3, 4]. There is only one large estuary, the Seine, which has a watershed area covering $79,000 \mathrm{~km}^{2}$. This area is home to more than a quarter of the French population and accounts for $40 \%$ of the country's economic activity and $30 \%$ of its agriculture, which adds numerous contaminants to the estuary [5]. The level of development in this area is highly diverse, with very urban zones, such as those on the Opal Coast extended to the southern part of the North Sea and the Calvados coast, and other zones with little or no development.

\subsection{Characteristics of the French Northeastern Atlantic Area}

Largely open to oceanic influences, the Atlantic continental shelf progressively gets narrower towards the south, where the abyssal plain is found only 20 nautical miles from the shore [3]. Two large estuaries-the Gironde in the south, with a watershed area of $85,000 \mathrm{~km}^{2}$, and the Loire in north, with a watershed area of $122,000 \mathrm{~km}^{2}$-feed the wide deep intertidal mudflats at their mouth [4]. In fact, the large mudflat along the southern coast of Brittany measures nearly $300 \mathrm{~km}$ in length. This coast presents strong contrasts, ranging between the development in harbor and urban areas (e.g., along the Gironde and Loire) and the large natural zones (e.g., the sandy shore of the 'Landes'). In the French Atlantic waters, the benthic communities are much more homogeneous and progressive from the intertidal zone, with its tidal range of less than $5 \mathrm{~m}$, to the bathyal or even the abyssal zone [1, 4] than in the English Channel, where they are often distributed in reduced-surface 'patches'. The sandy-mud sediment communities largely dominate the continental shelf, whereas the mud communities occupy all the bathyal depths under $200 \mathrm{~m}$ and the mudflats of the continental shelf in northern Gulf of Biscay.

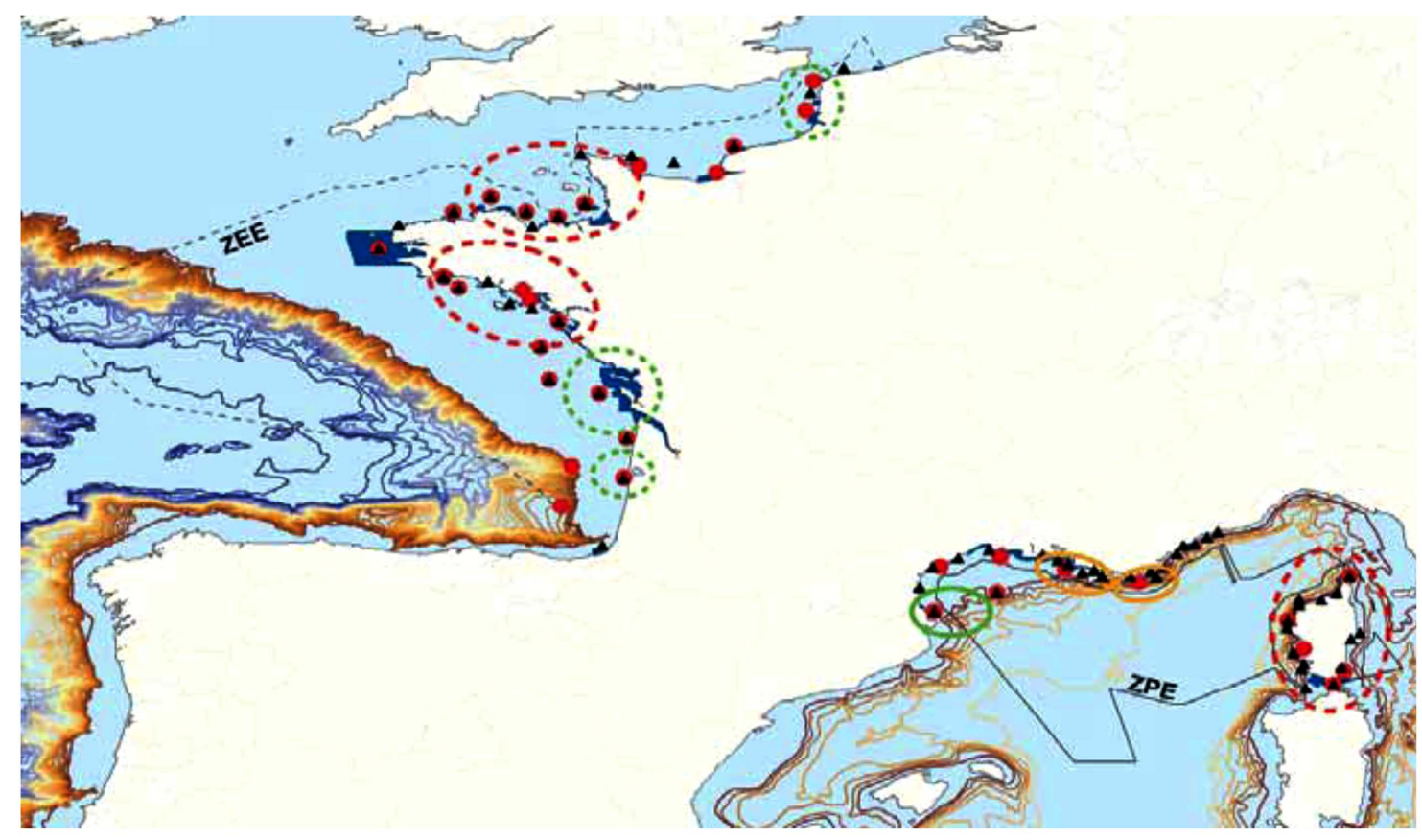

Fig. (1). Geographic priorities in the action strategy for metropolitan France (document AAMP, (see [35]). 


\subsection{Characteristics of the French Western Mediter- ranean Area}

The Mediterranean Sea has many particularities [2]. Mediterranean is a semi-enclosed sea, with very low amplitude tides and is subject to turbulent cyclonic circulation of its water masses. It covers about 3 million $\mathrm{km}^{2}$ and its inner basins have depths ranging between $2,500 \mathrm{~m}$ and 5,100 $\mathrm{m}$ (Matapan deep).

Concerning the French continental littoral, to the east, from the Italian border to the Gulf of Fos, the approximately $800 \mathrm{~km}$ coast is mostly rocky, with small bays and a narrow continental shelf notched by deep canyons; to the west, from the Spanish border to the Rhone delta $(250 \mathrm{~km})$, is a largely sedimentary coast with a continental shelf up to $100 \mathrm{~km}$ wide but with fewer canyons. Corsica is a mountainous island in the Mediterranean, with $980 \mathrm{~km}$ of coastline. Its western coastline has many coastal indentations (e.g., bays, coves and gulfs). The marine communities of the Mediterranean are quite well known $[2,6]$. The French continental littoral is extremely developed, with an average percentage of coastal artificialization of about $20 \%$, and is subject to multiple anthropogenic influences. The opposite is true for Corsica, whose littoral is still little developed.

\subsection{Anthropogenic Pressures on the Marine Environ- ment}

Several causes contribute to the rarity, or even the disappearance, of certain species or marine habitats. Four principal causes are usually recognized [7]:

i. $\quad$ Fishing. Fishing puts pressure on the target species.

ii. Habitat destruction. Whether the species are rare or abundant, the destruction of their vital environment poses a direct threat. The sea grass communities of Zostera or Posidonia, the Sabellaria reefs or maerl beds have completely disappeared in certain spots as a result of human activities.

iii. Pollution. Accidental oil pollution is the most spectacular due to its impact upon both communities and species. Less spectacular, chronic pollution, coming mainly from rivers on the continent, is just as harmful for the marine environment.

iv. Foreign invasive species. Foreign invasive species are increasingly numerous in the marine environment, and many of the species introduced are now part of our fauna and flora. The impact and dangers of introducing such species were raised during a workshop organized by the European Commission's DG XII Environment Program and the International Commission for the Scientific Exploration of the Mediterranean [8].

At the international level, the International Union for the Conservation of Nature (IUCN) established the evaluation criteria for the level of threat to species in three categories [7]. The Habitat Directive 92/43/EEC specifies that the species that are of interest to European Community are those that are in danger (except those within distribution limits), those that are vulnerable or those that are rare (i.e., small populations or those confined to a restricted geographical area), and the endemic species that require special attention because of the specificity of their habitat and/or the potential consequences of their exploitation on their state of conservation. The criteria retained by the IUCN are difficult to apply to marine invertebrates, for which objective data about the evolution of their populations is missing. However, applying these criteria pragmatically, Dauvin et al. [7] proposed that, for a species to acquire a protected status, at least one of the following conditions should be filled:

i. they should be subject to a particular harvesting pressure that could lead to a dangerous population reduction (i.e., the case of collection and edible species);

ii. they should be subject to a specific pressure that could lead to a deterioration of its habitat (e.g., overturned blocks, destruction of the substrate);

iii. their exclusive habitat should be subject to pressure from which it needs to be protected (e.g., pressure from development, pollution, overfishing).

\section{TOOLS FOR ENVIRONMENTAL PROTECTION AND MANAGEMENT}

\subsection{Existing Regulations}

Dauvin et al. [9] presented a summary of the major tools for controlling and/or preserving the natural heritage, as a follow-up to the work done for the project, 'Rationalizing Knowledge to Preserve Our Natural Heritage' as part of the LITEAU program [10]. We highlight here only the most important regulations for natural heritage preservation and protection:

- International conventions and European laws for the protection of littoral and marine natural areas and species - Ramsar Convention (wetlands); UNESCO's Man and the Biosphere (MAB) program (biosphere reserves); United Nations convention on the Law of the Sea (protection of the marine environment); OSPAR convention (protection of the North-East Atlantic marine environment) and World Heritage convention (protection of cultural and natural heritage); Directive 79/409/EEC of 2 April 1979 (wild birds); Directive 92/43/ EEC of 21 May 1992 (natural habitats, wild fauna and flora) [11]; Natura 2000 network; Barcelona Convention and Mediterranean Specially Protected Areas.

French laws pertaining to the regulation of natural heritage protection on the littoral - the Littoral Law (articles L.146-6 and L.146-4 of the Urban Planning Code), the regulations pertaining to protecting the maritime public domain, Conservatory of Coastal Areas and Lakeshores (CELRL) actions [10] (acquisition of natural spaces), national and regional nature parks, nature reserves, sites listed and registered as of interest for Natural Heritage, biotope decrees, French departmental acquisition policies pertaining to sensitive natural areas.

The following governmental decrees pertaining to protected marine flora and fauna should also be mentioned:

- $\quad$ list of protected birds (17 April 1981, 20 July 2005 and 24 March 2006);

- $\quad$ list of protected fish species (8 December 1988); 
- $\quad$ lists of protected Mediterranean species - two marine monocotyledons (19 July 1988) and six marine invertebrates (26 November 1992) (Please note that no marine invertebrate or plant species on the Atlantic and English Channel coast is protected);

- $\quad$ lists of protected marine mammals (17 July 1995), marine tortoises (20 December 2005), and the sturgeon Acipenser sturio (20 December 2004).

\subsection{Integrated Coastal Zone Management}

Integrated Coastal Zone Management (ICZM) is not simply a substitute for sectorial planning, but rather a process that avoids fragmentation by underscoring the links between the different domains. Deboudt et al. [12] have underlined the three periods that can be distinguished in the emergence of ICZM in France:

i. $\quad 1973$ to 1991 . This period, marked by a growing awareness of the need to protect France's natural heritage by limiting settlement in the coastal zones, was characterized by two general tendencies: first, coastal zone management was predominantly sectorial, and second, development had priority over preservation.

ii. $\quad 1992$ to 2000 . This period beginning in the early 1990 s was characterized by the acceptance of the concept of sustainable development as an integral part of environmental management. ICZM began to appear as an objective for coastal zone management at the international, European and national levels. The European Union experimented with ICZM strategies at 35 pilot sites in Europe, three of them in France: the Opal coast (i.e., the coastline along the eastern English Channel and the southern part of the North Sea), the Bay of Brest and the Bay of Arcachon [13, $14]$.

iii. 2001 to 2007. This more recent period was marked by the development of several transversal approaches to coastal zone management, as encouraged by interministerial policies. The traditional sectorial strategies for managing coastal areas and activities and the zoning practices on which these strategies were founded were called into question. The idea of replacing zoning-based methods with local projects came under consideration. During this last period, the Inter-ministerial Committee on the Sea (CIMER) (2003 and 2004) and the Inter-ministerial Committee on Territorial Planning and Development (CIADT) (late 2004) met, and the French government announced and began to implement the 2002 European Recommendation concerning ICZM. In September 2004, the DATAR presented an important report that outlined the context and the orientations of the new national, regional and local policies for French coastal zones, policies based explicitly on ICZM [9]. Following the report and the initial decisions, a Call for Projects was launched in January 2005 by the DATAR, which, with the General Secretary for the Sea (SGMER), was coordinating the implementation of the European Recommendation. Meur-Férec [14] has analyzed the characteristics of the 49 projects (i.e., the 25 projects selected and the
24 that were refused) in terms of ICZM principles, highlighting the strengths and weaknesses of the various implementation processes. The preservation of nature was the principle objective of the projects in the great majority $(85 \%)$ of the applications.

Recently, the strong implication of the Barcelona Convention behind the Madrid Protocol (i.e., the Mediterranean ICZM protocol) has to be considered as a major incentive for a sustainable protection and management of the littoral in all Mediterranean countries.

\subsection{The European Directives-Wild Birds (1979) and Habitats (1992)}

\subsubsection{The Wild Birds Directive}

The Wild Birds Directive (79/409/EEC of 2 April 1979) concerns the preservation of all species of wild birds living naturally on the European Member States' territory and aims to protect, manage and regulate these species. To do so, the Member States must take all the necessary measures to maintain or adapt their bird populations and their habitats, according to ecological, scientific, economic, recreational and cultural requirements. This Directive arose from RAMSAR Convention (1961). In the littoral, especially in the Mediterranean, this directive relates to the Special Protected Areas (SPA) included in the Natura 2000 network; there are 117 SPA in France. In addition, of the designated European Important Bird Areas (ZICO), 147 are entirely or partially in wetlands or coastal or maritime environments.

\subsubsection{The Habitats Directive}

The Habitats Directive (92/43/EEC of 21 May 1992) aims to preserve and protect the quality of the environment, including the preservation of natural habitats and wild flora and fauna on the Member States' territory. This Directive facilitates the general objective of sustainable development, taking into account the economic, social, cultural and regional requirements. In order to maintain or restore a species' natural habitat to a promising state of preservation, it was necessary to create a coherent European ecological network. This network, called 'Natura 2000', gathers the Special Areas of Conservation (SAC), which include the various types of natural habitats and species habitats in their natural distribution. Natura 2000 also includes the Special Protected Areas (SPA) designated in the 'wild birds' Directive (79/409/EEC). France has proposed sites covering $4,700 \mathrm{~km}^{2}$ located at sea, with many being littoral sites. Unfortunately, Appendix I of the Habitats Directive is particularly obscure in terms of the marine littoral domain, with the possible exception of the Posidonia meadows [15, 16]. This obscurity led France to draft a more explicit interpretation of the Coastal Habitats Handbook [17], for French operators using 'The Interpretation Manual of European Union Habitats', previously published by the European Commission in October 1999.

To date, 208 ZICO sites are located in littoral and retrolittoral communes or in the maritime public domain (www.environnement.gouv.fr) [18]. It has now been established that some of these sites are too large or too small, which will almost certainly engender management problems. Before looking at the protection plans established at the national level, it should be noted that the European Union's 
action in favor of littoral should have intensified, given that the European Commission adopted an European Strategy of "Integrated Coastal Zone Management" (ICZM) on 8 September 2000, and on 30 May 2002, it joined with the European Council and the European Parliament to suggest the adoption of a Recommendation concerning ICZM. These two texts are available on the Europe website: www.europa.eu.int/comm/environment/iczm [19].

\subsection{A Particular Area for the Natural Heritage: The Mediterranean Sea}

\subsubsection{The Blue Plan}

The Blue Plan was created for the Mediterranean more than 30 years ago and was signed today by 21 countries bordering the Mediterranean and the European Community in a context of a great international mobilization in favor of the environment [20]. This pioneering prospective systemic study of the relationship between the environment and development concerned all countries within the same region. It developed a regional environmental cooperation as part of the United Nations Environment Program's Mediterranean Action Plan (UNEP/MAP). The Blue Plan was responsible for 'making available to political leaders and decisionmakers all the information that will allow them to develop plans likely to insure optimal sustained socio-economic development without degrading the environment' and to help 'governments of coastal states in the Mediterranean region to increase their knowledge of the shared problems they have to face, both on the Mediterranean Sea and in their coastal areas'. This plan is a part of the movement towards sustainable development.

\subsubsection{The Barcelona Convention}

The convention known as the Barcelona Convention actually combines two Conventions - one 'for the protection of the Mediterranean against pollution', in force since 12 October 1978 and one 'for the protection of the marine environment and the Mediterranean coastline' in force since 9 July 2004-and several additional Protocols. At the beginning of 1990s, the international legal framework, particularly the Rio Summit, led the states bordering the Mediterranean to adopt a new Action Plan for the protection of the marine environment and the sustainable development of the coastal areas of the Mediterranean. They also adopted the amendments to the Barcelona Convention of 1978. Thus, starting in 1995, the Mediterranean states established:

\section{- a requirement of sustainable development,}

- the commitment of the signatories to apply the Precaution Principle and the Polluter Pays Principle, and

- a requirement of information and public participation in the decision-making process.

These states instituted the Special Protected Areas (SPA), which allowed preserving various typical coastal and marine ecosystems and the habitats that were in danger of disappearing, which had a reduced natural distribution surface, or were necessary to survival, reproduction and restoration of an at-risk animal and vegetal species or local endemic flora and fauna. In France, more than 120 SPA, covering a total of more than $2,915 \mathrm{~km}^{2}$, were thus established. At their Almeria meeting (Spain; 15-20 January 2008), the signatories recommended the adoption of an Integrated Coastal Zone Management (ICZM) protocol, called the Madrid Protocol.

\section{FRENCH POLICIES}

\subsection{The Conservatory of Coastal Areas and Lakeshores (CELRL)}

Originally created by the law published the $7 / 10 / 1975$, the CELRL [10] is a French public institution, which 'based on the recommendations of the interested municipal councils, executes a real-estate policy designed to protect the littoral and to respect of natural sites and the ecological balance' (www.conservatoire-du-littoral.fr). Its geographic and administrative jurisdiction is widespread, including geographical sectors bordering on the designated local administrative territories, when, along with the territories, these sectors constitute a ecological or landscape unit whose surface area is mostly within the territories. To carry out this policy, the CELRL can acquire the sites to preserve by amicable agreement, pre-emption, expropriation, donation or inheritance. Afterwards, these sites can only be separated from CELRL jurisdiction through an extreme complex and difficult administrative procedure. The CELRL territories can be considered true nature reserves in which the protection is maximum, given the appropriate management policies. As of 1 January 2009, the CERLR owned 125,000 hectares covering $1000 \mathrm{~km}$ of shoreline and 600 natural sites. The law of 27 February 2002 pertaining to 'democracy of proximity' makes official certain recommendations of the Le Pensec Report [21], widening the CERLR's jurisdiction [e.g., to include the Maritime Public Domain (MPD)], updating its competences and its legal means of intervention and affirming its role in the protection of the littoral, including the marine territories. Today, the CERLR manages four MPD sites, with a total surface of $55 \mathrm{~km}^{2}$

\subsection{The 'Littoral' Law of 1986}

In France, the law published on 1 March 1986 pertaining to 'development, protection and the valorization of the littoral' has become the corner stone for all action, public or private, on the littoral. This littoral zone is defined as 'encompassing a continuous space on both sides of the shore' and recognized as covering the totality of the communes bordering a sea, an estuary or a salt-water body. The communes' territories can be either public or private, and the maritime space that faces them, called MDP, is under the exclusive control of the State, since the 1682 'Colbert' ordinance. It should be specified, however, 'that none of the limits traced by the legal specialists, on land as well as at sea, is recognized as legal littoral border' [22]. This Law has been amended and modified several times, in particular by the insertion of the European Directives and International Conventions into French law, and is set by established precedents $[23,24]$. The aspects related to the protection and management of the marine environment and the terrestrial part of the littoral has gradually increased in importance since the law's promulgation. The French State intends 'to promote the sustainable development of the littoral and the integrated management of the littoral area, taking into account all the elements of the littoral system, both the sea 
and the land', trying especially to improve 'water quality' and to protect 'biodiversity'.

\subsection{Inventory of the Flora and Fauna in Natural Marine Zones of Ecological Interest}

Although research on marine species and communities has been done since the end of the 18th century, the knowledge this research makes available is often local and limited to the area around marine observatories and laboratories. Today, there is still little research pertaining to the natural heritage found throughout the mainland French coast [25]. The Red List of the threatened marine species was published in 1987 [26]. Since then, only two works have attempted to present the state of the state-of-the-art, respectively, for the Mediterranean marine biocoenosis [2] and the marine biocenosis of Atlantic, English Channel and the North Sea [1].

Given this situation, there is obviously a significant need for knowledge. Thus, the current evolution of the INTERREG programs, such as MESH (Mapping European Seabed Habitats, http://www.searchmesh.net/) and CHARM (Channel Habitat Atlas for Marine Resource Management, http://charm.canterbury.ac.uk/) for the Atlantic Coast are important. For example, in 2005, CHARM published the Atlas of the Habitats of the Marine Resources of the 'Pas-deCalais' [27]. In 2007-2008, CHARM2 continued with the entire Eastern basin of the English Channel, and beginning in April 2009, CHARM3 would spend three years extending the scale to the English Channel as a whole.

It was due to this need to improve our knowledge of the marine natural heritage that the Ministry of the Environment launched the Inventory of the Flora and Fauna in Natural Marine Zones of Ecological Interest (ZNIEFF) in 1982. 'ZNIEFF were conceived and coordinated at the national level by the Secretary of Flora and Fauna, and then the responsibility for coordinating the extension of the ZNIEFF at sea 'ZNIEFF-Mer' was given to the Natural Heritage Service of the National Museum of Natural History (MNHN) in Paris. A natural zone of ecological interest is 'a sector of the national territory in which scientific experts have identified remarkable natural heritage elements'.

Two great types of ZNIEFF are identified: 'Type I, which contain at least one remarkable or rare species/habitat, and Type II, which stand out from the rest of the territory because of the richness of the natural heritage that they contain' [28]. In 1988, the Provence-Alps-Azure Coast (PACA) region was the first to present a true network of 'ZNIEFF-Mer', backed with Land ZNIEFFs, for the whole littoral of the PACA region [28, 29]. At the request of the Ministry of the Environment, a comprehensive inventory of the mainland 'ZNIEFF-Mer' was undertaken in 1990, coordinated by the Natural Heritage Service and the Marine Invertebrate and Malacology Biology Laboratory of the MNHN [3, 30]. This inventory was extended to the overseas departments in 1995 [31].

\subsection{The LITEAU Program of the Ministry of the Environment}

In 1998, the Ministry of the Environment created the LITEAU program with the objective of providing scientific decision-support tools and suitable methods for the sustainable management of the littoral (http://www.liteau. ecologie.gouv.fr/) [32]. In this program, the littoral is understood in all its complexity as a Land-Sea interface, under the combined influence of offshore marine and atmospheric dynamics and the natural and anthropogenic input from coastal watersheds. The LITEAU program is part of the French scientific landscape; its operational focus complements the fundamental research carried out by the National Coastal Environment Program. This three-phase program has carried out research that is essentially multidisciplinary and open to the questions of the littoral stakeholders and managers. LITEAU I (1998-2002) dealt with seven principal topics, of which three were associated with ICZM. LITEAU II (2003-2006) initiated three new topics, including one clearly connected to ICZM. Launched in January 2007, LITEAU III embarked on a new programming phase with five principal topics, continuing the subject of ICZM but this time emphasizing both the theoretical and operational perspectives. In 2009, LITEAU III received financing for another two years, making of it one of oldest programs dealing strictly with the management of the French littoral.

As part of LITEAU I, a multi-disciplinary study examined the place of natural heritage preservation in the ICZM process [22]. IFREMER's support of ICZM has resulted in the development of appropriate tools for integrating knowledge that will be useful for public decisionmaking (www.ifremer.fr) [33]. These tools were developed in partnership with the multiple littoral stakeholders. The 'Grenelle de la Mer' (May-July 2009), a kind of negotiation between the French government and the littoral stakeholders, constitutes a unique opportunity to prepare a future sustainable development policy for the sea and the littoral. These negotiations offer the possibility of transferring knowledge, empowering environmental protection and development, observing and managing the coastal zone, encouraging biodiversity and its ecological services, or even establishing a volunteer observation network for the littoral.

\subsection{France's Strategic Action Plan for the Marine Environment}

Influenced of inter-ministerial policies, the beginning of the 2000s saw the development of transverse approaches to managing the littoral [34, 35]. Traditional strategies for managing the littoral zone and activities (e.g., natural heritage preservation) were thus called into question. Zoning plans, which were the basis of this type of management, were challenged and replaced by territorial projects. ICZM became a mid-term objective for managing the French littoral.

Some natural heritage preservation measures deserve to be mentioned, for example, the widening of the CELRL's jurisdiction (see the section above about the CELRL) and the 2005 publication of the Ministry for Ecology and Sustainable Development's Strategic Action Plan (SAP) [34] for the marine environment. The latter clearly conveys the willingness of the French national government to firmly commit to a maritime policy. The following five key directions for action were retained (http://www.liteau. ecologie.gouv.fr/) [32]: 
i. clarify the strategic choices to improve knowledge of the marine environment, including the continuation of thee ZNIEFF-Mer' inventories;

ii. contribute to a good ecological status of marine ecosystems and restore water quality;

iii. support a reasoned environmental management, natural heritage preservation and biodiversity by creating a network of marine protected areas (interior waters and territorial sea up to 12 miles), including the network Natura 2000 at sea;

iv. apply the sustainable sea resource management to the sectorial policies pertaining to sea activities; and

v. train, inform and raise the awareness of managers and the public and develop partnerships to sustain the maritime environment.

The actions engendered in these directions support two main objectives: increase our natural heritage knowledge, and integrate marine environmental protection in the ICZM process.

Two concrete results of this SAP were the creation of Natural Marine Parks, implementing a shared management of marine territories and resources with the goal of sustainable development, and the French Marine Protected Areas Agency (MPAA) [35], responsible for the coordination and long-term dynamism of the policy for the protection of the littoral and offshore, including any territory with a relationship to the maritime domain (e.g., national parks, nature reserves, special biotopes, Natura 2000 sites, CELRL sites). Created in 2005, the MPAA is a national public administration under the supervision of the minister in charge of environmental protection. It supports the State and the territorial authorities for developing strategies for creating and managing marine protected areas. It provides technical, scientific and administrative support to managers of marine protected areas, and it can also be entrusted with the direct management of these marine areas. It also provides the means for Natural Marine Parks. In addition, it contributes to the creation of international marine protected areas, in the context of France's international commitments in favor of marine and coastal bio-diversity (http://www.ecologie.gouv.fr/-Agence-des-aires-marinesprotegees-.html) [35].

\section{THE ASSESSMENT OF THE MARINE AREAS OF PATRIMONIAL INTEREST IN MAINLAND FRANCE}

\subsection{The Conservatory of Coastal Areas and Lakeshores (CELRL)}

The CELRL insures the protection of more than 500 coastal sites distributed relatively homogeneously along the coast of mainland France [10]. The Coastal Conservatory recently created four sites in the Maritime Public Domain. The most interesting site is the Chausey archipelago, which will probably become part of a future Marine Natural Park in the Normano-Breton Gulf.

\subsection{Protected Areas Under the French Marine Protected Areas Agency}

The MPAA [35] promotes protected areas for different reasons. Although there are no marine reserves in the
English Channel and the Atlantic Ocean, there are continental reserves that extend to the sea, such as the Seine estuary reserve. The Ushant Island, the Molène archipelago and various marine territories are part of the Armorica Regional Nature Park, which received UNESCO's label, Man and Biosphere, in 1989. The procedure aiming at designating a natural marine park in the Iroise Sea succeeded on 28 September 2007, and this protected area remains the only Marine Nature Park in France (Table 1). In the Mediterranean, the decree setting in motion the procedure creating Calanques National Park, a national park with both terrestrial and maritime territories, was signed on 5 May 2009. The boundaries of this Park are now being set. Various marine areas are protected, to differing degrees and according to different methods. In particular, the Port-Cros National Park and three regional marine reserves (CerbèreBanyuls in mainland France and Scandola and the Lavezzi Islands in Corsica) should be mentioned Table 1 (below) provides a general indication of the marine areas subject to different levels of protection.

Table 1. Categories of Marine Protected Areas in Mainland France's Waters According to http://www.airesmarines.fr/ (see [35])

\begin{tabular}{|l|c|c|}
\hline Type & Number & Surface $\left.\mathbf{( k m}^{\mathbf{2}}\right)$ \\
\hline \hline Site Natura 2000 (under way or projected) & 208 & 6,970 \\
\hline National Nature Reserve & 26 & 1,220 \\
\hline Iroise Marine Nature Park (Atlantic) & 1 & 3,550 \\
\hline Port Cros National Park (Mediterranean) & 1 & 13 \\
\hline $\begin{array}{l}\text { Coastal Conservatory's Marine Public } \\
\text { Domain }\end{array}$ & 4 & 55 \\
\hline Biotope Protection Decrees & 3 & 13 \\
\hline Blue Coast Park ((Local stakeholders) & 1 & 91 \\
\hline
\end{tabular}

To the protected areas mentioned in Table $\mathbf{1}$, it is necessary to add the International Sanctuary for Marine Mammals of the Mediterranean and the many fishing 'reserves' along the coastline of mainland France. These areas are too often the result of superposing redundant category measures.

In addition to the projects creating marine national parks (the first was the Iroise Marine Natural Park), the MPAA has been committed since its creation to extending the Natura 2000 network in the Exclusive Economic Zone (EEZ) of 200 nautical miles, identifying the important sectors and designating sites. On the coasts of the English Channel and the North Sea, and the Atlantic Ocean, in addition to the Iroise Marine Nature Park, other sites that have been shown to be of patrimonial interest since 1996 [7] would potentially be candidates for this kind of designation: the Chausey archipelago in the Normano-Breton Gulf, the Glénan archipelago and the Gulf of Morbihan in the south of Brittany, and the Gironde estuary and the Arcachon Bay on the Atlantic coast. Site study procedures for the three estuaries in Picardie (Somme, Authie and Canche) began in 2008 and those for the Gironde estuary and the Pertuis area began in June 2008. In the Mediterranean, the MPAA 
conducted a prospective study of the canyons (200-600 m) in the bathyal zone, and a Natura 2000 site project is being studied in the canyons off Banyuls. Other sites should soon be designated, especially the Cassidaigne canyons in the future Calanques National Park (Marseille).

\section{3. 'ZNIEFF-Mer'}

Nearly 15 years after its launching, the assessment of the 'ZNIEFF-Mer' (Marine ZNIEFF) is rather poor. Only the PACA Region has proposed a complete inventory [28, 29]. Currently, 100 'ZNIEFF-Mer' have been proposed and accepted by the Regional Science Council for Natural Heritage for this region. Some limited inventory operations were undertaken in other littoral zones in mainland France or are still under way: census of the population of Zostera in Brittany, census of the flora and fauna of certain intertidal zones in 'Basse-Normandie' and 'Haute-Normandie', a list of the sensitive species and marine macrobenthic communities in the 'Nord/Pas-de-Calais' region, as well as in the Mediterranean (i.e., Corsica and the 'LanguedocRoussillon' region).

As Dauvin [3] has underlined, several difficulties were encountered in carrying out this national inventory, both in terms of methodology (e.g., the difficulty of developing criteria for delimiting the zones, with a need to avoid inventorying zones that are too small), and the capacity to mobilize the inventory stakeholders. Indeed, contrary to the terrestrial environment, for which associations of naturalists are collecting most of the terrestrial data, the marine environment doesn't have very many active volunteer associations, and professional marine biologists are too few and are not easily available due to their current commitments to other regional, national and European programs.

It is also difficult to take into account the administrative divisions that are completely unsuited to the particularities of marine environment, characterized by the absence of absolute borders. What was obvious 10 years ago is even more obvious today, notably concerning the reduced numbers of zoological and botanical specialists in the marine observatories. The establishment of Natura 2000, the launch of the observation network REBENT (REseau Benthique, network benthic, http://www.rebent.org/) [36] after the Erika oil spill and then the Water Framework Directive (WFD) [34] required the funds of the DREAL (Direction Régionale de l'Environnement, de l'Aménagement et du Logement), the regional administration that was also responsible for the 'ZNIEFF-Mer' inventories. As a result, the DREAL could not invest in this action, which was consequently considerably delayed in spite of its obvious advantages. Part of the SAP calls for relaunching 'ZNIEFF-Mer' inventories.

\subsection{Some General Remarks}

When presenting an assessment of the various methods for protecting the marine environment of mainland France, both the positive aspects and the negative aspects should be underlined. Thus, we must point out the importance of the following three measures:

i. Coastal Conservatory (CELRL). This measure makes it possible to put many terrestrial sites of great interest under really strict protection. These sites are distributed throughout the littoral zones along the three maritime coastlines. Its extension to the Maritime Public Domain became possible, allowing a maximum degree of coherency in protecting the selected sites. However, the modalities of land acquisition, which are often limited, do not make possible to create a continuous line of land belonging to CELRL. It thus appears important, by means to be established, to facilitate the transfer of territories containing at-risk species or environments.

ii. Marine Protected Areas Agency. The recent creation of this Agency gave rise to hope for a better national coordination of the preservation and management policies. Its role in the extension of Natura 2000 network to the sea and in the prospective studies of the Mediterranean canyons with their large white coral populations should be highlighted. In these two cases, the pressure from the European Community was decisive. The establishment of an effective collaboration between this agency and scientists, notably from the universities and the CNRS, would be desirable.

iii. Regional Environment Administration. Particularly in PACA Region, this administration, through its dedicated services and the Scientific Regional Council for Natural Heritage, is with its experts directly involved in validating studies and documenting the objectives attained.

Also important is the role played by France in the Mediterranean, both in the context of the Blue Plan [20] and the Barcelona Convention. With its ancient privileged and well-maintained relationships, particularly at the scientific level, France could only profit from the implementation of the multiple initiatives aiming to protect and manage the Mediterranean Sea.

Unfortunately, it must also be considered regrettable that, with the exception of the PACA region and a few attempts here and there, the 'ZNIEFF-Mer' network could not be constructed at sea as it is everywhere on land. At the time of its creation, this tool became the basis for setting up the French Natura 2000 network when France decided to conform to the EU regulations. With that, the disappearance (which could be considered intentional) of competences in zoology and botany, of field naturalists, and even of ecologists is particularly critical in terms of the sea. Finally, the accumulation of regulations and statuses, including those of the employees; the stratification of administrative authorities and the competition among them; the French State with its potential conflicts with multiple authorities has led to a immense deceleration of activity and sometimes to failures that are incomprehensible to those who are not in the restricted circle of 'initiated'.

\section{CONCLUSION}

Of the methods likely to lead to the protection of the littoral marine environment and beyond in the EEZ and a reasoned sustainable management of this environment, ICZM is certainly the method that has the best chance of success. But it is not alone. In addition to the ICZM concept and potential applications, since the Rio Conference, the scientific communities, in an increasing number of States, have developed the concept of ecosystem-based management 
of marine resources [37]. This comprehensive and holistic approach focuses on the management of marine species and habitats and other natural environmental functions, integrating a distinct human component into this 'eco-sociosystem'.

However, aside from jealousy and the desire to appropriate this 'eco-socio-system', the difficulties of preserving and managing of littoral have several causes, which have been observed on the French coast of the Atlantic and the English Channel [38, 39] but can be transposed elsewhere, especially on the Mediterranean coast. Some of these causes can be highlighted: the lack of a precise definition of this land-sea interface; the separate jurisdictions of the two environments, and more precisely in terms of natural heritage, the superposition of incentive measures and regulations designed to protect certain species and certain areas of particular biological and/or geological interest; the need for objective fundamental knowledge on the status of the threats that weigh on the natural heritage in order to take measures that will allow the natural heritage to be preserved; the fine-tuning of indicators and indices; and the monitoring that makes it possible to evaluate the evolution of the species/environments over time [22].

At the European level, the analysis of the contents of the Green Book [40] underlines the need for better knowledge of the marine ecosystems, excellence in scientific oceanographical research and the enhancement of technology and innovation in the maritime sector. There is also a need to react quickly in order to protect resources, especially fish resources. Following the European debate about the Green Book, which lasted until June 2007, the future of ICZM in Europe can thus be considered from a more global perspective that incorporates all maritime and coastal issues. The European "Strategy for the Marine Environment", which appeared in June 2008, goes in this direction and recognizes the need to increase our knowledge of the marine environment by privileging an ecosystem approach. The Member States must now rapidly translate this directive in their institutions and mobilize the appropriate means. However, we must be clearly aware that each Country, even each bio-geographical area, will apply the suggested principles and methods according to their constraints and specificities. Thus, for examples, in the two countries bordering France - Belgium [41] and Italy [42] the species and the habitats to be protected in priority will be very different in scope and in scale.

Fundamental research still needs to be done. Multidisciplinary and trans-disciplinary (naturalists and social sciences) research groups exploring ICZM need to be set up, as was done in the LITEAU I program [22, 23]. There is also a need for coordination of the knowledge acquisition procedures and the preservation of the natural systems (e.g., completion of the 'ZNIEFF-Mer' inventory, extension of the Natura 2000 network throughout the EEZ). In France, the human and financial means of the multiple organizations with knowledge and competence concerning the marine environment (e.g., Universities, CNRS, IFREMER, IRD, CEMAGREF, Collège de France, and National Natural History Museum) should be brought together. In the future, the MPAA could assume this coordinating role for the natural heritage. It is also necessary to search for environmental quality indicators; to identify the significant at-risk environments, as was done in the OSPAR Convention [43] or the European Water Framework Directive (via the benthic network, such as REBENT implemented today only around the Brittany coasts); and to avoid the multiplication of marine habitat typologies, which are already too numerous $[15,16]$.

The role and the authority of the European Environment Agency must be increased in order to strengthen the cooperative links between the scientists in various European countries, who are too often limited to their academic disciplines. In addition, the scientists must strive to educate the citizenry of their various countries: i) transmitting their knowledge in a way that inspires learning, ii) simplifying their message so that it can be received by the non-initiated, and iii) getting involved as experts to insure a better comprehension of stakeholder decisions. There will always be an ethical subjective element to the preservation of emblematic species and territories, in relation to the cultural and social weight of the idea of preservation.

\section{ACKNOWLEDGEMENTS}

The authors would like to thank the two anonymous reviewers who provided very helpful comments on the initial draft of this manuscript. These comments permit us to improve it significantly. We are particularly pleased to thank Ms Lisa Ellen Spencer for her help with the (US) English version of the text.

\section{REFERENCES}

[1] Dauvin JC, Ed. Les biocénoses marines et littorales françaises des côtes Atlantique, Manche et Mer du Nord. Synthèse, menaces et perspectives. Patrimoine Naturels MNHN Paris 1997; 28: 1-359.

[2] Bellan-Santini D, Lacaze JC, Poizat C, Eds. Les biocénoses marines et littorales de Méditerranée, synthèse, menaces et perspectives. Patrimoine Nat MNHN Paris 1994; 19: 1-246.

[3] Dauvin JC. Mise en place des ZNIEFF-Mer en métropole: étapes, état d'avancement et actions connexes. Patrimoine Naturels MNHN Paris 2000; 42: 15-30.

[4] Dauvin JC. 2008. The main characteristics, problems, and prospects for Western European Coastal Seas. Mar Poll Bull 2006; 57: 22-40.

[5] Dauvin JC Coord. Estuaires Nord-Atlantiques : problèmes et perspectives. Bull. spécial Seine-Aval, septembre 2006: 1-80.

[6] Pérès JM, Picard J. Nouveau manuel de bionomie benthique méditerranéenne. Rec Trav St. Mar Endoume 1964; 31:1-137.

[7] Dauvin JC, Boucher P, Gofas S, Boudouresque Ch F, BellanSantini D. Marine Invertebrates of the French coasts and their conservation. In: Conseil de l'Europe, Colloque sur la Conservation, la gestion et le rétablissement des habitats des invertébrés : favoriser la diversité biologique; Killarney, Irlande, 26-29 mai 1996, Strasbourg 25 juillet 1996, T-PVS 1996; 51: 5-19.

[8] Boudouresque Ch F, Briand F, Nolan C Eds. Introducted species in European coastal waters. In Report on EEC/DG XII - CIESM workshop on introduced species in European coastal waters Monaco, 2-3 march 1993, 1994: pp 111.

[9] Dauvin JC, Lozachmeur O, Capet Y, Dubrulle JB, Ghézali M, Mesnard AH. Legal Tools for Preserving France's Natural Heritage through Integrated Coastal Zone Management. Ocean Coast Manag 2004; 47: 463-77.

[10] Conservatoire du Littoral et des rivages lacustres. Conservatoire du littoral - Fondation de France" Corderie Royale - BP 137 - 17306 Rochefort cedex 2000-2004 [updated and cited 2009 Jul. 1]. Available from: http:// www.conservatoire-du-littoral.fr

[11] EC Directive Habitats 1992. European Commission Council Directive 92/43/EEC on the Conservation of natural habitats and of wild fauna and flora. Available from: http://ec.europa.eu/ enviroment/nature/nature_conservation/eu_nature_legisltion/habitat s_directive/index_eu.htm 
[12] Deboudt P, Dauvin JC, Lozachmeur O. Recent developments in coastal zone management in France: The transition towards integrated coastal zone management (1973-2007). Ocean Coast Manage 2008; 51: 212-28.

[13] Ghézali M. Gestion intégrée des zones côtières : l'approche statutaire de la zone Côte d'Opale. Université du Littoral Côte d'Opale; Boulogne-sur-Mer 2000; p. 280.

[14] Meur-Férec C. De la dynamique naturelle à la gestion intégrée de l'espace littoral: un itinéraire de géographe. Habilitation à Diriger des Recherches, géographie. Université de Nantes 2006; p. 247.

[15] Dauvin JC, Bellan G, Bellan-Santini D. The Need for clear and comparable terminology in benthic ecology. Part I. Ecological concepts. Aquat Conserv Mar Freshw Ecosyst 2008a; 18: 432-45.

[16] Dauvin JC, Bellan G, Bellan-Santini D. The Need for clear and comparable terminology in benthic ecology. Part II. Application for the European Directives. Aquat Conserv Mar Freshw Ecosyst 2008b; 18: 446-56.

[17] Glémarec M, Bellan-Santini D. Les habitats marins. In Connaissance et gestion des habitats et des espèces d'intérêt communautaire. Habitats Côtiers. In : Bensettiti F, Bioret F, Roland J. Eds. Cahiers d'habitats. Natura 2000. Tome 2 + Cédérom. MATE/MAP/MNHN. Edition La Documentation Française, Paris 2005.

[18] Ministère de l'Ecologie, de l'Energie, du Développement durable et de la Mer[. Ministère de l'Ecologie, 92055 La Défense Cedex 2000-2009[updated and cited 2009 Jul. 1]. Available from: http:// www.environnement.gouv.fr/

[19] Commission européenne . Commission européenne, Direction de l'Environnement, rue de la Loi, Bruxelles, Belgique 2000[updated 2007 June 7 and cited 2009 August 1]. Available from: http://ec.europa.eu/environment/iczm/home.htm

[20] Benoit G, Comeau A. Méditerranée. Les perspectives du Plan Bleu sur l'environnement et le développement. Collection Monde en cours, bibliothèques des Territoires. Aube and Plan Bleu Eds. 2005.

[21] Le Pensec L. Vers de nouveaux rivages. Rapport ministériel sur la refondation du Conservatoire des Espaces Littoraux et des Rivages Lacustres 2000: p. 100

[22] Dauvin JC Coord. Gestion intégrée des zones côtières : outils et perspectives pour la préservation du patrimoine naturel. Patrimoine Naturels MNHN Paris 2002; 57: 1-346.

[23] Mesnard H, Lozachmeur O. Définition et perception de l'espace littoral. Le point de vue des juristes. In : Dauvin J.C. Coord., Gestion intégrée des zones côtières : outils et perspectives pour la préservation du patrimoine naturel. Patrimoine Naturels MNHN, Paris 2002; 57: pp. 29-32.

[24] Lozachmeur O. La nouvelle politique française du Littoral, In M.L. Destres et J. Filiaire Coord. Le Concept et les stratégies du développement durable: de l'international au local. L'Harmathan 2008; Collections Logiques Juridiques, Paris 197-237.

[25] Richard D, Dauvin, JC. Conservation strategies for French coastal areas. Aquat Conserv Mar Freshw Ecosyst 1996; 6: 205-14.

[26] Beaufort F, Lacaze, JC, Eds. Livre rouge des espèces menacées. Tome 2. Espèces marines et littorales menacées. Secrétariat de la Faune et de la Flore, Museum National d'Histoire Naturelle, Paris 1987: p. 260.

[27] Carpentier A, Vaz S, Martin CS, Coppin F, Dauvin JC, Desroy N, Dewarumez, JM, Eastwood PD, Ernande B, Harrop S, Kemp Z, Koubbi P, Leader-Williams N, Lefebvre A, Lemoine M, Meaden GJ, Ryan N, Walker M. Eastern Channel Habitat Atlas for Marine Resource Management (CHARM). Atlas des habitats des Ressources Marines de la Manche Orientale, INTEREG IIIA 2005 : p. 228 .

[28] Francour P, Bellan-Santini D. Management of the marine biodiversity in coastal areas through the French ZNIEFF network. Pelagos, special issue 2007: pp. 17-26.
[29] Bellan-Santini D. Les ZNIEFF-Mer en région Provence-AlpesCôte d'Azur, un outil de connaissance indispensable dans le processus de gestion intégrée des zones côtières. Océanis 2006; 30 (1): $115-27$

[30] Dauvin J.C, Bellan, G, Bellan-Santini D, et al. Typologie des ZNIEFF-Mer. Liste des paramètres et des biocénoses des côtes françaises métropolitaines. Patrimoine Naturels MNHN 1994; 12 (2nd ed): 1-64.

[31] Guillaume M, Doumenc D. Le bilan et les perspectives de la phase test de l'inventaire des ZNIEFF-Mer dans les DOM. Patrim Nat MNHN 2000; 42: 31-54

[32] Ministère de l'Ecologie, de l'Energie, du Développement durable et de la Mer Programme LITEAU MEEDDAT/CGDD/SR, 20, avenue de Ségur 75302 PARIS SP 072006 [updated 2009 April 30 and cited 2009 August 1]. Available from: $\mathrm{http} / / \mathrm{www}$.liteau.ecologie.gouv.fr

[33] Institut français de recherche pour l'exploitation de la mer Technopole de Brest-Iroise BP 7029280 Plouzané c2006 [updated 2008 Feb. 1 and cited 2009 August 1]. Available from: http://www.ifremer.fr/com/actualites/dev-durable-gestion-cote.htm

[34] MEDD (Ministère de l'Ecologie et du Développement Durable), 2005. Le plan d'actions stratégique du MEDD pour les milieux marins. Tome 1 Diagnostic et orientations : p. 118; Tome 2 Fiches action: p. 86

[35] Agence des Aires Marines Protégées. Stratégies des Aires Marines protégées. AAMP 42 bis quai de la Douane 29229 Brest Cedex 2, 2008.[updated 2009 April and cited 2009 August 1]. In French: http://www.aires-marines.fr/index.php?option=com_content\&task= view\&id=20\&Itemid=42. (in English: http://www.airesmarines.fr/index.php?option=com_content\&task=view\&id=3\&Ite mid=75).

[36] Institut français de recherche pour l'exploitation de la mer Programme "REBENT". IFREMER Technopole de Brest-Iroise BP 7029280 Plouzané 2002 dec. [updated 2009 April and cited 2009 August 1]. http://www.rebent.org/

[37] Arkema KK, Abramson SC, Dewbury BM. Marine ecosystembases management: from characterization to implementation. Front Ecol Environ 2006; 4: 525-32.

[38] Dauvin JC. Place stratégique du patrimoine naturel dans le processus de la Gestion Intégrée des Zones Côtières sur la façade atlantique, VertigO - la revue électronique en sciences de l'environnement, Hors-série 5 mai 2009, mis en ligne le 11 juin 2009. Available from : URL : http://vertigo.revues.org/index8212. html

[39] Dauvin C, Lozachmeur O. Mer côtière à forte pression anthropique propice au développement d'une gestion intégrée : exemple du bassin oriental de la Manche (Atlantique Nord-Est), VertigO - la revue électronique en sciences de l'environnement, Volume 7 Numéro 3 |décembre 2006, mis en ligne le 21 décembre 2006. Available from : URL : http://vertigo.revues.org/index1914.html

[40] European Commission. Green Book. Vers une politique maritime de l'Union: une vision européenne et des mers. 2006; p. 55. Available from http://ec.europa.eu/maritimeaffairs

[41] Rabaut M, Degraer S, Schrijvers J, et al. 2009. Policy analysis of the «MPA-process» in temperate continental shelf areas. Aquat Conserv Mar Freshw Ecosyst 2009; 19: 596-608.

[42] Carrada GC, Coiro P, Russo GF. Eds. Le aeree marine protette del Mediterraneo. Atti del Convegno Internazionale «Le aeree marine protette del Mediterraneo», 28 Sep. 2002. San Arsenio (Napoli, Italy); Quadern uomo natur 2003; 1: p. 174.

[43] Ardron J. The challenge of assessing whether the OSPAR network of marine protected areas is ecologically coherent. Hydrobiology 2008; 606: 45-53.

(C) Bellan et al.; Licensee Bentham Open.

This is an open access article licensed under the terms of the Creative Commons Attribution Non-Commercial License (http://creativecommons.org/licenses/by-nc/3.0/) which permits unrestricted, non-commercial use, distribution and reproduction in any medium, provided the work is properly cited. 